\title{
Library Access and the Mobility of Users
}

\begin{abstract}
Equal access to library resources and services by users from outside areas has long been regarded as an ideal situation within the United States. As increasing numbers of scholars make use of libraries not affiliated with their home-base institutions or communities, however, the burden of financing these services to outside users weighs even heavier upon the libraries delivering them. This paper points to some of the problems raised by this growing scholarly mobility.
\end{abstract}

T

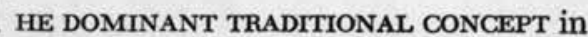
the United States regarding information has been that it is largely in the public domain and therefore should be equally available to all who need it. There are, of course, some situations where this general proposition is clearly excessive. The public interest itself dictates that copyrights and other patents, confdential data, and such other proprietary information always remain restricted. But, in large measure, society would appear to be best served when the information it possesses can be equitably delivered where and when it is needed, without regard to the user's status, wealth, or other differentiating characteristics.

This ideal obviously has never been attained. Information is certain to cost someone money. Wealthy communities, and communities that have benefited from extensive philanthropies, have been able to develop great strength in their library services. Others have developed substantive library strength through ex-

$M r$. Kaser is a professor at the Graduate Library School, Indiana University, Bloomington. traordinary husbanding of lesser or local resources. Communities with none of these capabilities, on the other hand, have sometimes foregone library service entirely. In the higher education arena, some high quality institutions have accumulated vast library strengths, whereas others make do with only meager library resources. In short, equal access to information does not exist.

Yet among librarians it is almost an article of faith that equality of access to information should be sought-that it is a laudable, legitimate, and, indeed, almost an attainable goal. They recognize their responsibility to manage their library resources in accord with the best interests of their own institutions, a responsibility that often finds itself in conflict with another, perhaps higher, accountability, which calls for them to serve the larger community. It is an unfortunate and simplistic but frequently accepted notion that when a librarian appears over-attentive to the library's concerns, he manifests the Natural Depravity of Man, and when he leans to community interests, he displays the Natural Goodness of Man. What is probably more often the case, however, is that the librarian has made the materials 
under his stewardship as widely available as he feels he can without being called to an audit by his governing body.

This dichotomy in the responsibility of librarians has probably been most obvious in interlibrary loan. As long as a library lent and borrowed at approximately the same rate there was no problem; but the librarian who found himself lending much more than he borrowed was soon lying awake nights wondering how to justify the imbalance to his own students, some of whom had gone into debt to attend this university rather than a less expensive one, or to his own community that had perhaps overtaxed itself in order to gain a quality of library service higher than that of its neighbors. Where is justice?

In recent years this bibliothecal insomnia has been extended by the growing population of "free-standing students" and unaffiliated scholars. They are not a new phenomenon, but they are increasing in numbers. Peripatetic scholars have existed since time immemorial, and more of them probably used the library at seventh-century St. Gall than scholars from St. Gall used library resources elsewhere-perhaps to the consternation of some unchronicled and insomniac abbot-but at least, in those days, all libraries were under the general oversight of the far-flung Mother Church.

Perhaps in the new "open university" plan in Great Britain, the University Grants Committee has assumed a role analogous to this former responsibility of the Church. In the United States, however, where a variety of open-university, university-without-walls, and external-degree experiments are springing up rapidly, no similar, monolithic superstructure exists to lend fiscal as well as intellectual integrity to such innovations. The fund implications resulting from this growing mobility of academic library users deserve early attention, and they will not be easy to resolve. It is the purpose of this paper to point out a number of the more immediate concerns related to this issue.

The problem is clear. Whereas the traditional college student incurred library cost only in his home library-a cost that could be easily predicted, identified, and budgeted by his home institution-the new "free-standing student" seeks out and uses the library service he needs wherever it can be found or wherever it is convenient for him. It is important to recognize that his library costs are in no way diminished by this new mobility; they do not, as some funding authorities would like to believe, simply merge imperceptibly into the landscape. His library costs, rather, are relocated from a single library-ofresidence to any number of other libraries, bringing along accounting problems, which no one yet knows quite how to handle.

Ideally such mobility by unaffiliated scholars should not be impeded in any way, as far as they indeed need access to libraries apart from their own institutions. Everything reasonable should be done to accommodate them, as on a national level this would reduce the excessive costs of unnecessarily duplicating resources and services provided by libraries. Most of the larger libraries, however, and many of the smaller ones will find it impossible to foster untrammeled access to their resources by outsiders unless some kind of funding comes with them to reimburse their total out-ofpocket costs. Without such mobility of funding the whole system will eventually collapse under its own weight, as the interlibrary loan structure is now threatening to do. Funding library services for the mobile scholar may be likened to funding gasoline purchases by the freeway traveler. Oil companies frequently hold monopolistic franchises on sections of freeway so as to reduce unnecessary duplication of their services; yet no one expects travelers to carry credit cards for all oil companies. Rather such service 
stations pump gasoline for all comers and charge the transactions against not only their own but also other oil company credit cards. Perhaps a common system could be developed among libraries so that all library uses were debited against the user's card with a similar periodic recharge of service costs from the servicing libraries to the user's respective fund bases.

Such a scheme would require a relatively elaborate bureaucracy for implementation. Many questions would need to be answered, and numerous systems and subsystems would need to be designed before it could be instituted. Who would eventually pay? Presumably the user's home institution or company would ultimately pay, or perhaps his tax base if he lacked institutional affiliation, or perhaps the user himself. Should the serving library concern itself over a potential user's "credit rating"? Should it fear the possibility that he might overrun his own or his institution's ability or willingness to pay? Probably not; filling stations do not fret about such things. Would this mean that every user would have to be issued an allocation of library service by his home institution or other fund base, which he himself would be held responsible for not overdrawing? Probably not; some scholars presently incur heavy costs for their libraries-ofresidence without their librarians threatening to cut off their service because of "insufficient funds."

Among the many problems in funding library service for scholars "on the road," so to speak, perhaps two stand out above all others in their complexity. The first questions how scholars' fund bases would know what to budget for their uses elsewhere. The vagaries of scholarly peregrinations are inscrutable; a somewhat predictable mobility will always occur from locations of bookish poverty to those of bibliothecal wealth. Mobility, however, takes place for myriad and seemingly imponderable other reasons as well, none of which would be easy to anticipate. Can we study them to the point of being able to predict and budget for them?

The second major problem would be to determine an appropriate pricing structure for the serving library. Libraries have always had difficulty identifying the true and discrete costs of their several "product lines." Asking how much it costs to answer a reference question is like asking how much it costs to take a trip; neither question is easy to answer. The actual transaction cost of circulating a book is perhaps relatively easy to calculate, but a book cannot be circulated unless it is owned by the library in the first place, and the intricate machinery of selection, acquisition, processing, and shelving the book-often over many years but with few uses-is more difficult to calculate, and is estimated in different ways by libraries. Furthermore the factors, and their costs, by which individual institutions develop their unique and respective levels of library expectation boggle the mind. If, as some have encouraged, libraries could settle upon an "irreducible unit of productivity," in effect an "atom" of library activity, service price schedules could be easily estimated. No libraries, however, have done so, and none appear likely to do so soon. It might be that library services are too diverse and too interactive for them ever to do it.

The same problems, of course, inhere in schemes of paid interlibrary access as exist in schemes of paid interlibrary loan. These include

1. the degree of the rights of the unaffiliated user in the library to which paid access is obtained; in the past libraries have tended to accord only "second-class" service to outsiders; and

2. the comparative advantages of locally determined as opposed to 
nationally determined service price schedules; if the former were adopted, unaffiliated users might "shop around" for the cheapest service, whereas if the latter were chosen, the funding agency might impose performance standards as contract specifications.

There is, however, one major cost advantage to interlibrary access over interlibrary loan. With interlibrary loans, staff members have to verify citations of requested items, determine locations if held, fetch them from the shelves, record their absence from the collections, prepare them for mailing, discharge them when the transaction is complete, and return them to the shelves. The direct labor costs of these activities in libraries are high and are unlikely to be reduced soon. The on-site user, however, does all these things for himself, thus eliminating an expensive "overhead" item from the library's cost. If, of course, "total social costs" rather than library costs are being considered, this point becomes moot.

Other ways might be conceived to fund unimpeded access to library collections and services. An obvious and dramatic alternative would be to "nationalize" all library holdings under some kind of "federal library authority" and to operate them in accord with national interest. An appropriate sum would probably have to be settled upon present owners of libraries so taken over, and, to be realistic, this amount would have to be very high. Where nationalized collections remained in their current sites the implications for the previous owners might be minimal, because they would continue to be easily available to the scholars in those areas. In other cases, however, the national interest might dictate that whole collections or libraries be removed from such traditional, pastoral locations as Ithaca, Hanover, and Chapel Hill, into major population centers-a move that would totally emasculate the academic programs of their previous owners.

To charge for units of library service, as was discussed earlier, is to recover cost at point of output. Another way of funding unhampered library access might be to do it at point of input. Some university libraries in state-supported institutions have already begun making their services available to all state residents, on the basis either of the fact or the rationalization that part of their total budgetary allocation at point of input was to enable them to serve unaffiliated users.

Librarians must take care, however, that they do not commit themselves to incurring substantial costs at point of output in return for small budgetary increments at point of input. The total costs of universal access are high and are unlikely to differ much over time, whether calculated at input or at output. Funding library service at point of input can be compared to ownership of a home-with taxes, maintenance, and liability being equated with library selection, processing, and storage-and library funding at point of output compared to home rental-where only use is purchased rather than equity. In libraries, as in real estate, the true total costs of renting are not greatly at variance with the costs of owning. Perhaps a more apt analogy would be the difference between paying green fees to play golf (point of output) and buying a membership in the country club (point of input).

In the background of any discussion on universal access to libraries looms the high cost of rendering adequate library service under any circumstances. Many academic libraries presently spend in excess of $\$ 500$ a year per student. It must be remembered, however, that this amount is an average. Many students do not use libraries at all, and others use them only minimally. The cost of serv- 
ing heavy library users, therefore, might exceed $\$ 2000$ annually. An unaffiliated user is, first of all, a user, and in many cases it may also be assumed (because he has made a special effort to get here) that he is a heavy user. He might, moreover, require extraordinary staff services because of his unacquaintance with this particular library, its collections, and its services. Thus the average cost of serving the unaffiliated user on a continuing basis seems likely to exceed the average cost of serving affiliated matriculants, or their local class equivalents.

These are only a few of the considerations that the higher education community must soon face if student mobility is to be realized; there are many others. Although equality of library service does not exist, nor is it likely to be attained, it is a deserving goal. Any major steps toward this goal will require evaluation of the costs and benefits, and discussion of alternative courses. Research and experimentation in the field are needed and in order. 